\title{
'No consensus' on FDA role in gene tests
}

[WASHINGTON] A US government task force has dropped plans to call for the Food and Drug Administration (FDA) to extend its regulation of genetic tests. It has decided instead not to pronounce on the issue in its final report, due to be published next month.

Neil Holtzman, director of genetics and public policy studies at the Johns Hopkins Medical Institutions, who is chairman of the Task Force on Genetic Testing, said last week that the 15-member group "is not going to recommend that FDA extend its authority to assessing genetic-test services".

Holtzman said there was no point in pursuing the issue further because of a lack of "consensus" on the matter between members of the panel, which is made up of scientists, ethicists, industry and consumer representatives.

In a closed session last month, a small majority of the group voted against calling for increased FDA involvement in regulating genetic tests.

At present, the FDA monitors genetic tests that are developed and sold as kits through doctors and other providers, but does not monitor those marketed by companies as in-house 'services'. No genetic-test 'kits' as such are known to exist; instead, companies have developed tests as services, thereby avoiding FDA surveillance.

In provisional recommendations published in the Federal Register in February, the task force said that one option would be for the FDA to monitor even those genetic tests marketed as services, requiring pre-market FDA approval when such tests were considered to require particularly stringent scrutiny (see Nature 385, 477; $1997 \&$ 384, 101; 1996).

Tests would be considered to fall into this category on the basis of criteria such as their ability to predict serious future disease in healthy individuals and their offspring.

But more than 50 comments received since February in response to the provisional recommendations appear to have swayed the task force against calling for FDA involvement.

The American Society of Human Genetics called the approach "heavy handed" and without "clear rationale", while the College of American Pathologists said the additional mandate would "substantially compromise" the FDA's ability to carry out its current work. The American Medical Association called the suggestion "ill advised".

According to Patricia Murphy, a repre- sentative of the genetic-test developer OncorMed, who is a member of the task force, "Essentially half of [the task force] strongly believe [FDA] is not the right agency. They don't have geneticists, they don't have the experience, they don't have the money or the resources and they don't have the interest." She added that the Centers for Disease Control and Prevention were already well placed to carry out such work.

In other final recommendations, the task force will urge that commercial and private developers of genetic tests should be required to submit test-development protocols to local ethics panels called Institutional Review Boards, or equivalent bodies. Tests would also have to be approved by external review bodies before being used in clinical practice. Separately, both the authority and the extent of its jurisdiction of a suggested National Genetics Board would be scaled back from original proposals.

The task force was established by the Working Group on the Ethical, Legal and Social Implications of Human Genome Research of the National Institutes of Health and the Department of Energy, to make recommendations for the safe and effective development and use of genetic tests.

Meredith Wadman

\section{Nirex chief expected to lose seat on UK's nuclear waste panel}

[LONDON] Michael Folger, chief executive of Nirex, the company responsible for disposing of Britain's nuclear waste, is expected to lose his place as a member of the government's Radioactive Waste Management Advisory Committee (RWMAC).

A routine internal review by the Department of the Environment (DoE) is to recommend that Folger's term of office is not renewed. He has served on the committee since 1991. A source close to the DoE confirms that Folger's position is "under consideration". A final decision, however, rests with the new Secretary of State for the Environment, who will take office after the general election on 1 May.

A spokesman for Nirex says the company will not comment on what it considers to be "speculation". But the decision, if taken, would be yet another blow for Nirex. The company has effectively been forced to abandon plans to bury intermediate-level nuclear waste in a planned deep repository in the northwest of England since the environment secretary refused to allow the company to build an experimental research facility to test the site geology.

A decision not to renew Folger's term will not, however, be entirely unexpected.
Observers such as environmentalist groups have often said that Folger's presence on RWMAC could be seen to compromise the committee's independence, particularly when RWMAC is called upon to review Nirex's own proposals, such as its plans to build the experimental rock laboratory, or more recently, the company's peer-review arrangements. One source says Folger's presence on RWMAC gave the impression that "Nirex were reviewing themselves".

RWMAC is made up of experts and lay members. Its members are drawn from areas including the nuclear industry, universities, local government, an environmentalist group and the National Health Service.

News of Folger's possible removal has provoked a mixed reaction. The environmentalist group Friends of the Earth believes the move is long overdue. Rachel Western, senior nuclear research officer at Friends of the Earth, says, "it is essential that the government now receives advice from a broader-based community of environmentalists and scientists".

Current and former members of RWMAC, on the other hand, remain divided. Some consider the DoE's recommendation to be an overreaction. "I can't see a problem," says one former member. "RWMAC is an independent committee, and we didn't feel gagged at all."

Other RWMAC sources believe that Folger's position was difficult to justify, given that the committee does not include relevant experts from the anti-nuclear environmentalist movement. "RWMAC should either have representatives from all sides, or be composed entirely of independent academics. If environmentalist groups are excluded, the same should apply for the nuclear industry," said one.

A DoE spokesman says that RWMAC members are chosen for their professional expertise rather than their affiliation. But one critic points out that Folger, a former civil servant with a background in finance, did not appear to be the ideal choice to represent professional expertise in nuclear waste management.

Meanwhile, Nirex has denied suggestions that it is planing to make redundant a large number of scientists. At a board meeting earlier this month, the company decided not to appeal against the government's decision to refuse its application to build the rock laboratory, presaging speculation that redundancies were likely (see Nature 386, 423; 1997).

Ehsan Masood 